\title{
Factors That Predispose Secondary School Teachers to Examination Malpractice in Edo State, Nigeria
}

\author{
Jimoh B. Olatunbosun \\ Dept of Educational Foundations and Management, Faculty of Education \\ Ambrose Alli University, Ekpoma, Nigeria \\ E-mail: jimohbasil_2009@rocketmail.com \\ Omoregie O. Eunice \\ Dept of Educational Foundations and Management, Faculty of Education \\ Ambrose Alli University, Ekpoma, Nigeria
}

Received: August 23, 2011

Accepted: December 16, 2011

Published: March 1, 2012

doi:10.5539/res.v4n1p245

URL: http://dx.doi.org/10.5539/res.v4n1p245

\begin{abstract}
This study investigates the factors that predisposed secondary school teachers to examination malpractice in Edo State and how they rate these factors. The study participants were 988 teachers selected from 9885 teachers in public and private secondary schools in the State. The descriptive (survey) design was used in the study because it is a self-report research that would enable the researchers to collect data from teachers in order to determine their predisposition to examination malpractice. A questionnaire developed by the researchers was used to collect the needed data. The data collected was analyzed using percentages, mean and standard deviation. The findings of the study revealed that anomie was a major significant variable that predisposed teachers to examination malpractice. Other variables, though not significant, were societal/parental factor, teaching/learning environment, teacher factor and student factor. Based on the findings, the researchers recommended, among others, that teacher training programmes should be re-designed with more emphasis on civic and value education and that government should improve on its funding in the education sector.
\end{abstract}

Keywords: Predispose, Examination malpractice, Academic fraud, Quality assurance, School success

\section{Introduction}

The value and functionality of any educational system lie in its ability to actualize the goals of education. In educational systems, world over, the examination process makes the difference. The goals of national educational systems and indeed national development become elusive if examination ethics is not encouraged and instituted (Nwadiani, 2005). Till date, examinations still remain the best tool for an objective assessment and evaluation of what learners have acquired after a period of schooling. Thus, any action that undermines examinations poses a great threat to the validity and reliability of examination results and certification.

Unfortunately, the process of examination in Nigeria's secondary schools leaves much to be desired. This is because of the phenomenon of examination malpractice that has become endemic in the educational system. The Examination Malpractice Act (1999) explains examination malpractice as any act of omission or commission by a person who in anticipation of, before, during or after any examination fraudulently secure any unfair advantage for himself or any other person in such a manner that contravenes the rules and regulations to the extent of undermining the validity, reliability, authenticity of the examination and ultimately the integrity of the certificates issued. In Nigeria, the last two decades have witnessed an increase in incidents of examination misconduct. Evidences abound of increasing involvement in examination malpractice by students, teachers and parents (Vanguard, 2005; Weekend Pointer, 2005; Daily Independent, 2004). The incidence of examination malpractice has become so widespread that there is virtually no examination anywhere at all levels and outside the formal school system that there is no one form of sharp practice or the other. 
Although examination malpractice is neither a recent phenomenon nor is it peculiar to Nigeria or Africa (Awanbor, 2005), its rate of increase is a global issue. Studies have revealed many different forms of academic cheating (Coston and Jenk, 1998; Caruana, Ramaseshan and Ewing, 2000). According to these studies, there are four general areas that compromise academic cheating. These are cheating by using authorized materials during academic activity; fabrication of information; plagiarism and helping other students engage in cheating (facilitating). The prevalence of academic dishonesty has also received considerable attention in literature. In a survey sent to more than 15,000 students at 31 major universities, it was found that over $60 \%$ admitted cheating at least once (Meade, 1992). In an anonymous survey of students at a major university, over two-third reported cheating at least once (Hollinger and Langz-Kaduce, 1996). In Nigeria, the alarming rate of increase in examination malpractice in secondary schools in Nigeria calls for concern from all stakeholders in the education sector. It has been widely reported that parents and teachers aid and abet examination malpractice directly or indirectly (Nigerian Tribune, 2009). Parents go to the extent of bribing their way through to ensure that their wards get unearned grades while teachers encourage examination malpractice because they lack the zeal to work but want to be praised for job not done (Alutu and Aluede, 2006).

The phenomenon of examination malpractice seems to be aggravated by the large scale and shameful involvement of dishonest and greedy teachers, school heads, parents and all those who take part in examination administration (Ijaiya, 1998). The prominence assumed by this malady in the school system has become a source of concern to stakeholders in the education industry. The examination process has become endangered to the extent that certification has almost lost its credibility in the country. Certificates no longer seem to reflect skill and competence. Accusing fingers have been pointed at teachers, school heads, parents, students, examination officials and even security agents as those responsible for examination malpractice in the school system. It is against this background that this paper examines the factors that predispose secondary school teachers' to examination malpractice in Edo State and how teachers rate these factors.

\subsection{Factors responsible for examination malpractice}

The phenomenon of examination malpractice seems to be influenced by many factors. According to Ivowi (1997), lack of confidence as a result of inadequate preparation, peer influence, societal influence, parental support and poor facilities in schools are some of the factors responsible for examination malpractice. School programmes, teaching learning environment, the teacher, the student, over value of certificates, decadence in the Nigerian society (anomie) and parental support as some other factors responsible for examination malpractice in the Nigerian educational system (Awanbor (2005), Nwandiani (2005), Badmus (2006), Okafor (2006), Ayua (2006), Azare (2006) and Aminu (2006)).

\subsection{Anomie and examination malpractice}

Anomie is one factor that seems to predispose teachers to examination malpeactice in Edo State. Anomie is conceived as a breakdown in the cultural structure due to disjunction between the cultural norms and goals and the socially structured capacities of members of the group to act in accord with them (Merton, 1968). In this conception, cultural values may help to produce behaviour that is at odds with the mandates of the values themselves. Anomie gives birth to aberrant behaviour and non-conformity, which is a symptom of dissociation between culturally prescribed goals and socially prescribed means for realizing these goals. A society that places exceptionally strong emphasis on goal achievement without a corresponding emphasis on institutionalized means of achieving these goals is bound to exert pressures on some members of the society that may eventually resort to the use of any expedient means in achieving these goals irrespective of whether the means employed is legitimate or not (Merton, 1968).

The process whereby exaltation of the end generates a de-institutionalization of the means to the end occurs in many societies where the two components of the social structure are not highly integrated. Contemporary Nigerian society appears to lay emphasis on success goals without equivalent emphasis on institutional means of attaining success. The response is the general decadence that pervades the country today. Everything in Nigeria these days seems to be driven by the desire for success irrespective of the means used in achieving success (Jimoh, 2009). The attenuation of this over time is the anomie that now characterizes the Nigerian society. The social vices bedeviling the society seem to have permeated the entire segments of the education sector. The manifestations are moral decadence, loss of family values, cultism, indecent dressing and examination malpractice that now characterize the education system of the country. The societal emphasis on success-goals, irrespective of the means employed in achieving these goals, may have pressurized some persons in the education industry to strain toward anomie. Such persons have resorted to the use of illegitimate procedures in achieving success in examinations. 


\subsection{School programmes}

According to Awanbor (2005), school programmes are the building blocks of education used by the teacher and the learner to bring about the desired change in behaviour of the learner.

A good school programme must have relevance and value meaning for the present or future life of the individual, that is, it must be functional and utilitarian. In addition, school programmes

must be dynamic for them to be worthy of the ingredients of teaching and learning. The nature of school programmes in Nigeria is such that does not rapidly respond to the change catching up with education in the world. These inadequacies in the school programmes have created lean ways for students and teachers to engage in sharp practices during examinations in order to earn underserved grades and promotion.

\subsection{Teaching or learning environment}

Learning in the 21st century requires new skills, new tools and new knowledge. One of the greatest challenges faced by the school system in Nigeria is how to ensure that students are equipped to flourish within a wide array of learning and work communities. This is what the world of today demands that the school must find appropriate technology to facilitate and support. The teaching learning process is enabled by curriculum design, pedagogical design, implementation quality, outcomes assessment and resource provision. These constitute the what, how and why of the education system. These five factors, which are the characteristics of the environment in which teaching and learning take place, include class size, infrastructures, general structure, objectives of syllabus and other environmental factors. Recent studies have revealed that availability of instructional materials and facilities, teachers' knowledge of the curriculum, area of specialization and qualification and teacher commitment determine the levelof performance of curriculum implementation roles of teachers as measured by the degree to which the prescribed methods and assessment techniques are employed by the teacher (Badmus, 1993; Okobia, 2006). Uwadiae (1997) in a study of school factors as determinants of examination malpractice found, among others, that $66 \%$ of the variance in examination malpractice was determined by such school factors as examination facilities, school performance, class population and school location. Studies have indicated that the environment within the classroom or examination setting, as established by the instructor, can have significant impacts on cheating (Roig and Ballew, 1994; Genereux and McLeod, 1995; Crown and Spiller, 1998; Whitley, 1998).

Unfortunately, the teaching and learning environment in the school system in Nigeria is bedeviled by dearth of learning materials, over crowded classrooms, inadequate teaching staff, obsolete facilities and equipment and dilapidated school buildings. Studies show that space facilities and equipment are in short supply at all levels of education in Nigeria (Badmus, 1993; Omoifo, Badmus, and Awanbor, 2002; Nigerian Academy of Education, 2004; Okobia, 2006). The implication is that the learning environment only promotes absorption of information that makes the students to use surface learning approaches that promotes passive acceptance of ideas and information. If learners are empowered with quality teaching by quality teachers using good learning strategies and authentic evaluation that enhance learning outcomes in a conducive teaching learning environment, most learners would learn better and will not think of examination malpractice.

\subsection{The teacher factor}

The teacher is a very significant variable in the business of schooling. The quality of instruction and the end products of education depend to a large extent on the job performance of the teacher. The quality of teaching is a key determinant of learning. This depends on the quality of people in teacher education and their continuing professional development as well as their work practices and working environment. Teacher quality as measured by teacher ability and teacher background account for about 40 percent of variance in student learning (Badmus, 2006).But teachers cannot provide experiences and activities that guide students' progress and development towards understanding of ideas if they themselves do not know these ideas; neither can they provide experiences that challenge students understanding if they themselves share the same misunderstanding (Badmus, 2006). According to Erakhumen (cited in Badmus, 2006), primary and secondary school teachers lack adequate knowledge of subject matter they teach because teachers who trained them were not properly empowered. As at 2004/2005 session, $25.65 \%$ of teachers in Nigerian secondary schools were not professionally qualified (Teachers' Registration Council of Nigeria (TRCN), June, 2006) The quality of teaching to be given by this category of teachers is likely to be low, and this will have adverse effects on the learners.

The job performance problem of the teacher is further compounded by other extraneous variables such as poor working conditions, societal pressures and inadequate remuneration. These have endangered the teachers in their own profession. According to Abayeh (1996), poverty/poor conditions of service are a chief factor that encourages teacher involvement in examination malpractice. Presenting a selected average salary scale per annum of 
post-primary school teachers in Nigeria, Abayeh (1996) observed that the poverty level of staff in post primary schools was most probably at its zenith. According to him "it is so bad that the staff will do anything to augment their miserable monthly wages (that is when it is eventually paid)". From the data he obtained, $90 \%$ of staff would willingly turn a blind eye if properly induced, or give assistance directly or indirectly, for an agreeable price during an examination. The study also revealed that a small percentage of staff / teachers $(10 \%)$ will give assistance to students for sexual favours.

Most schools in the country today may not possess what it takes to produce students with quality results, yet their proprietors (government, individuals and cooperate organizations) may tie the promotion and other rewards of their teachers to students' performance. In Oyo, Ondo and Sokoto States, for example, school principals and head teachers were to be held responsible for the failure of their students in any external examinations. This has compelled teachers to aid their students to cheat in order to earn promotion and escape being sanctioned by their proprietors. In the same vein, "lazy teachers who have not taught would at all cost want their students to pass examinations since it is seen as a measure of good teaching" (Alutu and Aluede, 2006).

\subsection{Student factor}

Examination is a veritable tool in all fields of education. It provides meaningful information on examinees for decision-making. Today, the spirit of dogged attention to study by students in order to pass their examinations on their own without engaging in any form of sharp practices has been thrown to the dogs. There is that notion among students of today that nobody can actually pass his/her examination without some external assistance or what they call "ECOMOG" (Ochoga, 2002). The students no longer want to read but to cheat and get results. Majority of students no longer have confidence in themselves; they believe they need some form of assistance if they must pass their examinations. In another related study, Ercegovac and Richardson (2004) examined attitudes of students in nineteen colleges with regard to academic cheating and plagiarism in the United Kingdom. They found that factors such as lack of trust, alienation from school, large classes, collaborative learning styles, and lack of understanding what plagiarism really meant were positively correlated with academic cheating and plagiarism.

The introduction of the Global System of Mobile Telephones (GSM) in the country has revolutionized examination malpractice in the school system. With the aid of GSM phones, students store a lot of academic information into their handsets for direct use in examination halls or for onward transfers via SMS to other students any where in the country. In the same vein, answers to multiple choice questions are sent to students in the hall via SMS or direct dictation facilitated by the use of ear piece. The emergence of technological devices has spawned new and more sophisticated approaches to dishonest conduct during examinations (Cizek, 2003). Students with personal digital assistants or cell phones can beam or call data silently from across a classroom, or with a cell phone from anywhere off the school environment.

\subsection{Societal or parental factor}

The future of any nation is largely a function of the children who are the leaders of tomorrow and the quality of education they receive. Regrettably, successive governments have neglected the welfare and education of Nigerian children. The decadence in the society is perhaps the result of this neglect. The Nigerian society as it stands today seems to be founded on faulty/fragile education, political, economic, physical and social environment that cannot produce a better tomorrow (Ojeikere, 2004). The society is bedeviled with social and economic ills such as corruption, nepotism, "godfatherism", cultism etc. Corruption has posed a serious threat to private and public morality in Nigeria. According to Aderibigbe (as cited in Ojeikere, 2004), "the nature of the scenario could be likened to the average Nigerian child being born to dishonest parents, taught all through his life by dishonest teachers grows up to live in an environment that has accepted dishonest practices as a way of life". Sommers and Satel (2005) opined that the dishonesty in academic activities in schools is a reflection of the much broader erosion of ethical behaviour that has become commonplace in a society that tends to support self-centredness over concern for others.

There is no doubt that the social vices bedeviling the society have permeated the entire segments of the education sector. The society's involvement in examination malpractice is a reflection of the syndrome to make quick money without hard work. The society is in an era of "settlement". The settlement culture seems to have eaten deep into the fabrics of the society to the extent that its use to aid examination malpractice is just a tip of the iceberg (Adeyegbe, 1994). The financial and other rewards accruing to participants of examination malpractice are enormous and unimaginable. Parents and guardians are ready to give encouragement and pay costs because they desperately want their children and wards to acquire certificates.

Parental indiscipline, abuse of wealth and unrealistic expectations and demand on children are components of parental involvement in examination malpractice. It is common knowledge that some parents over work their 
children leaving no time for them to study after school hours. Some others are so much after money that they do not have time to give proper supervision to their children talk less of monitoring their progress at school. Some others still believe that with their wealth they can catapult their children to any heights in the society even if it involves buying question papers and bribing teachers and invigilators to ensure that their children pass examinations. In the same vein, some parents force their children into wrong choices of courses or programmes even when the children do not have the academic potentialities for such courses. As a result, the children get involved in examination malpractice in order to meet up with their parental expectations. There is a general agreement among educators that an increasing number of parents seem obsessed with having their children performbetter than classmates, regardless of the steps taken to attain desired results (Nichols and Good, 2004; Baker and LeTendre, 2005).

Again, the economy within which the society operates is so bartered and unpredictable that there is too much reliance on certificate or paper qualifications before survival of anyone can be assured. According to Ihejirika (2005), the monopoly of prestige, which paper qualification enjoys lures every Nigerian into committing various sorts of examination malpractice since companies, government, organizations, private employers of labour and institutions all insist on certificates as pre-conditions for employment and admission.

\section{Method}

\subsection{Method of study}

The descriptive (survey) design was used in the study because it is a self-report research that would enable the researchers to collect data from teachers in order to determine their predisposition to examination malpractice.

\subsection{Participants}

The population of this study was made up of all the teachers in public and private secondary schools in Edo State. There are 9885 teachers in both private and public secondary schools in Edo State (Ministry of Education Edo State, 2009). A sample size of 988 teachers; representing $10 \%$ of the population was used for the study. This was obtained through the following procedures.

\subsection{Procedures}

First, the number of teachers in each of the eighteen local government areas that make up Edo State were identified; second, the number of teachers selected from each local government based on the sample size of $10 \%$ was determined; third, the number of teachers selected from

each sub-group in each local government area was determined, fourth, teachers were randomly selected from the sub-groups in each local government identified by the researchers. The sub-groups are sex of the teacher, location of the teacher (rural and urban) and ownership of school (public and private). Proportional sampling was applied in selecting samples from each sub-group. Based on the sampling procedure, 417 female teachers and 571 male teachers were selected, 552 teachers were selected from schools in the rural areas, 436 teachers from schools in the urban areas, 330 teachers from private schools and 658 teachers from public schools. All the teachers selected for the study have a minimum educational qualification of Bachelor's degree in Arts, Social Sciences or Physical Sciences. Of the 988 teachers, 520 were below the age of 40 years while 468 were above the age of 40 years.

\subsection{Measures}

The instrument that was used in this study was a questionnaire developed by the researchers and titled Examination Malpractice Predisposition Questionnaire (EMPQ). The questionnaire was divided into two parts, the bio-data section and the section on factors responsible for examination malpractice. Section A elicited information on the bio-data of the teachers. These included respondents' sex, school location and ownership of school while section

B contained 30 items that elicited information about the factors responsible for respondents' predisposition to examination malpractice. The thirty items were based on anomie, school programmes, teaching/learning environment, teacher factor, student factor, societal/parental factor. Items 1-5 sought information on anomie, items 6-10 sought information on school programmes, items 11-15 sought information relating to teaching/learning environment, items 16-20 sought information on teacher factor, items 21-25 sought information regarding school community/parental factor and items 26-30 sought information about student factor. A four-column Likert type rating scale was provided at the end of the items for the respondents to tick the column that best expressed their predisposition to examination malpractice. The range of the responses were Strongly Agree $(\mathrm{SA})=4$, Agree $(\mathrm{A})=$ 3 , Disagree $(\mathrm{D})=2$, and Strongly Disagree $=1$. A pre-test of the instrument was carried out to determine its reliability. The split-half reliability procedure was used in determining the reliability coefficient. This yielded a reliability coefficient of .88 . 
To determine the factors that predisposed teachers to examination malpractice, the mean score of all the responses on each of the factors was computed and compared with the set minimum point for involvement in examination malpractice, which was 12.5. On a four-point Likert type scale with five items raised to measure a specific factor, the baseline for favourable perception of a factor was any value that is 12.5 and above. To determine the minimum point for favourable perception of a factor, the numerical value of 2 attached to the response "Disagree" was added to 3 , the numerical value attached to "Agree" and divided by 2 to give 2.5. This was now multiplied by 5 , the number of items under each factor, to get 12.5 that is the set minimum point for favourable perception of a factor.

In order to determine the rating of the factors, the responses to the five items under each factor in Section $\mathrm{B}$ of the questionnaire were collated and summed up in two broad categories of "Agree" and "Disagree". The responses for "Strongly Agree" and "Agree" were merged and placed under the "Agree" column while the responses for "Disagree" and "Strongly Disagree" were merged and placed under the "Disagree" column. The percentage of the responses to the five items under the "Agree" column was calculated for all the factors. The resultant percentage for each factor was now ranked from the highest to the lowest. This ranking enabled the researchers to determine the strength of influence of the factors on teachers' predisposition to examination malpractice.

\section{Results}

The result analyses of the respondents from the research are presented under the following phases:

\subsection{Factors predisposing teachers to examination malpractice}

The factors predisposing teachers to examination malpractice are presented in the Table I.

Data on Table 1 reveals that Anomie has a mean response score of 12.63, which is the highest while Student Factor has a mean response score of 11.03, which is the lowest. From the mean of the responses on Table 1, Anomie appears to be the main variable that influences teachers' predisposition to examination malpractice. Factors such as School Programmes, Teaching/Learning Environment, Teacher Factor, School Community/Parental Factor and Student Factor are not major predisposing factors to examination malpractice.

It is interesting to know that Anomie is the major variable that influences teachers' predisposition to examination malpractice. This revelation could be the result of the interaction

that exists between the school and the society. The school being part of the society will be influenced, either negatively or positively, by whatever happens in the society. Other factors that

were investigated in the study seem not to have a strong influence on the disposition of teachers to examination malpractice. This could be due to the fact that these other factors do not directly influence the behaviour and attitude of teachers to social issues and life in general.

\subsection{Teachers' ratings of the factors predisposing them to examination malpractice}

Teachers' ratings of the factors are presented in Table II.

As revealed by data on Table II, anomie has a mean response score of 12.63 and a percentage ranking of $54.7 \%$, the highest while student factor has mean response score of 11.03 and a percentage ranking of $35.6 \%$, the lowest. Based on the rating, anomie appears to be the factor that exerts the strongest influence on teachers' predisposition to examination malpractice; followed by School Community $\backslash$ Parental Factor, Teaching $\backslash$ Learning Environment, Teacher Factor, School Programme and Student Factor respectively.

\section{Discussion}

The study revealed that anomie was a major factor that predisposed teachers' to examination malpractice. This may be adduced to the malintegration of cultural structure with social structure, that is, the dichotomy between cultural goals and the institutional means to achieve the goals. This finding appeared to be in consonance with the views of Badmus(2006) Awanbor (2005), Okafor (2006), Ayua (2006), Azare (2006) and Aminu (2006), who identified school programmes, teaching learning environment, the teacher, the student, over value of certificates, decadence in the Nigerian society and parental support as some factors responsible for examination malpractice. In the same vein, Ivowi (1997) identified lack of confidence as a result of inadequate preparation, peer influence, societal influence, parental support and poor facilities as some of the factors responsible for examination malpractices.

Anomie, which this study has revealed to be the main factor that predisposed teachers to examination malpractice, includes societal influence, parental support and decadence in the society. This could be the reason for the high rating of school community/parental factor as a factor that predispose teachers to examination malpractice. Besides, the school being a sub-structure of a super-structure (the society) will definitely be affected by what goes 
on in the society. This perhaps is the reason for the high performance of this factor in the rating of factors that predispose teachers to examination malpractice. The high rating of anomie as a factor that predisposes teachers to examination malpractice gave credence to the Merton's (1968) assertion that deviant behaviour is a consequence of anomie created by the malintegration of cultural structure with social structure. The assertion is hinged on the premise that the society pushes individuals towards deviance by overemphasizing the importance of success while failing to emphasize the importance of using legitimate means to achieve that success.

Contemporary Nigerian society appears to be characterized by a heavy emphasis on success and wealth without a corresponding emphasis upon legitimate means and avenues to be used in achieving success. The societal emphasis on success-goals, irrespective of the means employed in achieving these goals, may have pressurized some teachers to strain towards anomie. Examination malpractice is a form of deviance because it is a deviation from the acceptable institutionalized social norm of conduct during examination. The societal pressure that has forced some teachers to be predisposed to examination malpractice is a reflection of the general decadence in the Nigerian society. Everything in Nigeria these days seems to be driven by the desire for success irrespective of the means used in achieving success (Ojeikere, 2004). He further reiterated that the Nigerian society, as it is constituted today, seems to be founded on faulty/fragile education, political, economic, physical and social environment that cannot produce a better tomorrow. The country is bedeviled with social and economic ills such as cultism, moral decadence, embezzlement, social injustice, corruption, etc. It has become a society where the custom is to decorate miscreants, knaves, scam artists and violators of national trust with national honours and appoint them to exalted public officers (Ndibe, cited in Ojeikere, 2004). The country is like a commercial venture where everyone is out to make quick money in order to be able to afford the good things of life. The teacher is no exemption as his involvement

in examination malpractice is an avenue to make quick money and thus be able to afford the good things of life.

Contrary to the views of Badmus (2006), Awanbor (2005), Okafor (2006), Ayua (2006), Azare (2006), Aminu (2006) and Ivowi (1997), school programme teaching/learning environment, teacher factor and student factor are not considered by teachers as major predisposing factors to examination malpractice. This is not to say that these factors do not impact on examination malpractice; what it implies is that their impact may not be significant. This study has revealed that these factors are not major dispositional variables in examination malpractice. These factors could significantly impact on the quality of education being given to the Nigeria child, but not on teachers' predisposition to examination malpractice.

\section{Implications of Findings to Educational Management in Nigeria}

The findings of the study have some implications to educational management in general and school administration in particular. The study revealed that anomie is the major factor that predisposes teachers to examination malpractice. Unfortunately teachers who are supposed to be role models and custodians of societal ethics and values have been engulfed by anomie. The response of some teachers to the decay in the society leaves much to be desired. Therefore, there is a need to re-appraise teacher training programmes in Nigeria. Educational managers, curriculum experts and other stakeholders in the education sector need to come together to re-design the country's teacher training programmes to include courses in civic education with emphasis on value education. Teacher training programmes at all levels should be reviewed to include courses in citizenship and value education in order to enhance the role performance of the teacher. Teacher training programmes as they are today have failed to prepare the teachers to deal successfully with the challenges of daily living and respond to the ever increasing and more complex changes in the environment. Greater emphasis should be placed on teacher professional development through regular seminars and workshops. The teacher, by virtue of his training and job, is a role model and builder of character.

In addition, the Teachers Registration Council of Nigeria (TRCN) should be more pro-active in its activities and alive to its functions and obligations to teachers. There should be a collaborative effort of all professional education bodies in the country to actualize the goal of professionalizing teaching and making it more attractive. Although the Federal Government of Nigeria upwardly reviewed Teachers salary by $27 \%$ in 2008 , yet this has not taken effect in most states of the Federation. Though a good step in the right direction, government should be more sincere in its pronouncements and more committed to implementation of educational policies.

\section{Recommendations}

The researchers advocate that a more pragmatic approach to the problem should be adopted. An Examination Malpractice Commission should be created to address this social evil. Such a body should be independent, devoid of government interference, and provision for its funding backed by law. Besides, the Commission should be empowered to prosecute offenders who contravene the Examination Malpractice Act. 
A special welfare package should be put in place for teachers and other examination officials to discourage them from financial and material inducements from students, parents and others who may want to subvert the examination process.

Nigeria's education system appears to be too certificate oriented. It is high time the nation took certificates no more as passports to jobs or higher education; more emphasis should be placed on skill acquisition and competence. There is the need for a comprehensive social re-engineering of the society to salvage what remains of the societal norms and values so that the problem of examination malpractice could collectively be tackled.

Nigeria's funding efforts of education is low, and its budgetary priority for the education sector is even lower. An improvement on the current funding efforts will provide conducive teaching and learning environment devoid of academic fraud and other sharp practices associated with the assessment process in the school system.

\section{Conclusion}

Examination malpractice is a social evil that can damage society to the extent of possibly leading to a failed state. It has very serious economic, political and social consequences. Examination malpractice renders the goals of education invalid. The actualization of the goals of education will continue to be a mirage if the scourge of examination malpractice is not eradicated from the system. The country will end up producing graduates who lack the knowledge, skill and competence to exploit the resources of the nation. Besides, the graduates will lack the right type of values and attitude needed for survival in a globalized economy.

Malpractice leads to irreversible loss of credibility. A country that becomes noted for examination malpractice loses international credibility because documents emanating from such country will be treated with suspicion. Consequently, certificates awarded by such country's educational institutions are disbelieved. Such country's educational institutions are as good as dead as far as international cooperation in education is concerned.

The fight against examination malpractice cannot succeed if corruption continues to be endemic in the country. Examination malpractice has wrecked unimaginable havoc to the entire fabric of Nigeria. It is a hydra headed problem that requires a multidimensional approach to its resolution. Any effort aimed at resolving this problem must be collaborative, that is, involving all stakeholders in the education sector, if not, such effort will end up being an exercise in futility.

\section{References}

Abayeh, O. J. (1996). An analytical study of factors influencing examination malpractices in post-primary institutions. Paper presented at the WAEC monthly seminar.

Adeyegbe, S. O. (1994). The new and widening dimensions of examination malpractices. Paper delivered at the WAEC monthly seminar.

Alutu, A. N. G. \& Aluede, O. (2006). Secondary school students' perception of examination malpractices and examination ethics, Journal of human ecology, India: Kamlar-Raj Enterprises, 20(4).

Aminu, J. (2006). Examination malpractice in Nigeria: roots, sustenance, endemicity, dangers and assailance. Keynote Address Delivered in a Two-Day Summit on Examination Malpractice in Nigeria Organized by the House of Representatives Committee on Education Held at the Shehu Musa Yar' Adua Centre, Abuja, August, 15-16.

Awanbor, D. (2005). Credentialing Process in the Nigerian Educational System. Keynote Address Presented at the First Annual Conference of the Faculty of Education, Ambrose Alli University, Ekpoma, November, 10-12.

Ayua, I. A. (2006). Confronting legal issues in examination malpractice: the law, prosecution and judicial processes. Speech Delivered at a Two-Day Summit on Examination Malpractice in Nigeria Organized by the House of Representatives Committee on Education Held at the Shehu Musa Yar' Adua Centre, Abuja, August, 15-16.

Azare, G. D. (2006). Accountability in teaching/learning environment and examination malpractices. A Paper Presented at a Two-Day Summit on Examination Malpractice in Nigeria Organized by the House of Representatives Committee on Education Held at the Shehu Musa Yar' Adua Centre, Abuja, August, 15-16.

Badmus, G. A. (1993). Matrix sampling as a technique for setting objective questions to beat examination malpractice. in Maduka, C. (Ed) Examination malpractice: causes, implications and remedies, Benin City: Faculty of Education, University of Benin. 
Badmus, G. A. (2006). Acountability in teaching/learning environment and examination malpractices. A Paper Presented at a Two-Day Summit on Examination Malpractice in Nigeria Organized by the House of Representatives Committee on Education Held at the Shehu Musa Yar' Adua Centre, Abuja, August, 15-16.

Baker, D. \& LeTendre, G. (2005). National differences, global similarities: World culture and future of schooling. Stanford, CA: Stanford University Press.

Caruana, A., Ramaseshan, B. \& Ewing, M. T. (2000). The effect of anomie on academic dishonesty among university students. The International Journal of Educational Management, 14, 23-30. http://dx.doi.org/10.1108 $/ 09513540010310378$

Cizek, G. (2003). Detecting and preventing classroom cheating: Promoting integrity in assessment. Thousand Oaks, CA; Sage Publications.

Coston, C. T. M. \& Jenks, D. A. (1998). Exploring academic dishonesty among undergraduate criminal justice majors: A research note. American Journal of Criminal Justice, 22, 235-248. http://dx.doi.org/10.1007/BF0288 7259

Crown, D. F. \& Spiller, M. S. (1998). Learning from the literature on collegiate cheating: A review of empirical research. Journal of Business Ethics, 17, 683-700.

Daily Independent. (2004). Principal arrested for impersonation at exam hall, September 28th.

Ercegovac, Z. \& Richardson, J. V. Jr. (2004). Academic dishonesty, plagiarism included, in the digital age: a literature review. College and Research Libraries, 301-312

Federal Republic of Nigeria. (1999). Examination malpractice act. Lagos: Government Press

Genereux, R. L. \& McLeod, B. A. (1995). Circumstances surrounding cheating: A questionnaire study of college students. Research in Higher Education, 36, 687-704. http://dx.doi.org/10.1007/BF02208251

Hollinger, R. \& Lanza-Kaduce, L. (1996). Academic dishonesty and the perceived effectiveness of counter measures: An Empirical survey of cheating at a major public university. NASPA Journal, 34, 292-306.

Ihejirika, J. C. (2005). View Point: The Nigerian society is to blame for examination malpractice. [Online] Available: http://nm.onlinenigeria.com/templates/?a $=3605 \& \mathrm{z}=12$

Ijaiya, N. Y. S. (1998). Eradicating examination malpractices: a macro-theoretical framework option. Nigerian Journal of Development Issues: Socio, Political Economic Development, 2 (2), 72-85.

Ivowi, U. M. O. (1997). Examination malpractices: profile, causes, warning signs, case studies, prevention and detection strategies cited in Onyechere, I. Promoting Examination Ethics: the challenges of a collective responsibility. Lagos: Potomac Books.

Jimoh, B. O. (2009). Investigation of the factors that predispose secondary school teachers to examination malpractice in Edo state. Unpublished Ph. D. Dissertation, Ambrose Alli University, Ekpoma.

Meade, J. (1992). Cheating: Is academic dishonesty par for the course? Prism, 1(7), 30-32.

Merton, R. K. (1968). Social theory and social structure. New York: The Free Press.

Nichols, S. \& Good, T (2004). America's teenagers. Mahwah, NJ: Lawrence Erlbaum and Associates.

Nigerian Academy of Education (NAE) (2004). Report of a study of educational problems in Nassarawa State of Nigeria. Lagos: NAE.

Nigerian Tribune. (2009). Students and exam malpractices. Lagos: Nigerian Tribune, 12th February.

Nwadiani, M. (2005). Curbing examination malpractice in the Nigerian educational system. A lead paper presented at the First Annual Conference of the Faculty of Education, Ambrose Alli University, Ekpoma, November, 10-12.

Ochoga, D. A. (2002). Urban-rural migration among prospective SSCE students as a foul strategy for passing SSCE examinations: implications and recipe for effective control. Paper presented at the WAEC monthly seminar.

Ojeikere, M. B. (2004). Examination activities in Nigeria: victims of social vices. Paper delivered at the WAEC Monthly Seminar, 10th September.

Okafor, F. C. (2006). Confronting environmental issues in examination malpractice: societal and professional support". A Paper Presented at a Two-Day Summit on Examination Malpractice in Nigeria Organized by the House of Representatives Committee on Education Held at the Shehu Musa Yar' Adua Centre, Abuja, August 15-16. 
Okobia, E. (2006). An assessment of implementation of national junior secondary school social studies curriculum in Edo State.

Omoifo, C. N.; Badmus, G. A. \& Awanbor, D. (2002). Education and achievement in the early career of the University of Benin graduates. Repot of a Tracer Study Sponsored by SIDA for Association of African Universities.

Roig, M. \& Ballew, C. (1994). Attitudes toward cheating of self and others by college students and professors. The Psychological Record, 44, 3-12.

Sommers, C. \& Satel, S. (2005). One nation under therapy. New York: St. Martin’s.

Uwadiae, I. J. (1997). School factors as determinants of examination malpractice in the senior secondary school Mathematics examination in Nigeria. Unpublished Ph. D. Thesis, University of Ibadan.

Weekend Pointer (2005) Father writes GCE exam for son, $6^{\text {th }}$, August

Whitley, B. E. (1998). Factors associated with cheating among college student: A review. Research in Higher Education, 39, 235-274. http://dx.doi.org/10.1023/A:1018724900565

Vanguard. (2005). Rising exams malpractices. Vanguard Comment, $12^{\text {th }}$, October.

Table 1. Factors predisposing secondary school teachers to examination malpractice

\begin{tabular}{|l|l|l|}
\hline Predisposing Factors & Mean & SD \\
\hline Anomie & 12.63 & 2.37 \\
\hline School Programme & 11.33 & 2.88 \\
\hline Teaching/Learning Environment & 11.36 & 2.68 \\
\hline Teacher Factor & 11.35 & 2.80 \\
\hline School Community/Parental Factor & 12.24 & 2.97 \\
\hline Student Factor & 11.03 & 2.92 \\
\hline
\end{tabular}

Table 2. Rating of the factors responsible for examination malpractice

\begin{tabular}{|l|l|l|}
\hline Predisposing Factors & Mean & $\%$ Rating \\
\hline Anomie & 12.63 & $54.7 \%$ \\
\hline School Community/Parental Factor & 12.24 & $51.8 \%$ \\
\hline Teaching/Learning Environment & 11.36 & $40.1 \%$ \\
\hline Teacher Factor & 11.35 & $39.9 \%$ \\
\hline School Programme & 11.33 & $37.1 \%$ \\
\hline Student Factor & 11.03 & $35.6 \%$ \\
\hline
\end{tabular}

